\title{
RALÉ À BRASILEIRA
}

\author{
Armindo dos Santos de Sousa Teodósio \\ Professor do Programa de Pós-graduação em Administração - PUC Minas \\ teodosio@pobox.com
}

Submissão: $16 / 02 / 2012$

Aprovação: 21/09/2012

Um elemento central na construção da vida humana em sociedade é a referência que se constrói sobre a identidade e valores que diferenciam um grupo de outros. Essa dimensão é encontrada tanto em pequenas comunidades locais até alcançar o Estado-nação moderno. Consolidadas nos últimos séculos, as nações se tornaram referência para a delimitação e acesso à cidadania, sobrepondo-se e atritando com as percepções em torno de garantias de direitos construídas pelos grupos locais inseridos em determinada região que se circunscreve formalmente em uma nação.

No caso dos países periféricos, a construção da identidade como nação é sempre perpassada pela idealização que desenvolvem sobre os países centrais, numa relação complexa que revela dinâmicas herdadas dos processos de colonização e dominação. Em terras tupiniquins, a construção social da ideia de brasilidade caminhou por trilhas tortuosas, encontrando-se de tudo um pouco, muitas vezes operando em bases dicotômicas: busca de higienização e purificação racial e enaltecimento da miscigenação e pluralidade étnica, sentimento de inferioridade pelo desenvolvimento incompleto e celebração da suposta originalidade, flexibilidade e capacidade de "navegação social" brasileira, para se mencionarem apenas os grandes eixos do debate social e político em torno da brasilidade. É nessa esteira que aprendemos a valorizar as ideias e debates propostos por intelectuais do calibre de Gilberto Freire, Sérgio Buarque de Holanda, Florestan Fernandes e Roberto DaMatta. Dessa forma, se consolidaram no imaginário social brasileiro, não apenas nos círculos acadêmicos, as noções de democracia racial, miscigenação étnica, cordialidade, jeitinho brasileiro e outras tantas que sempre oscilam entre certo saudosismo daquilo que nunca fomos, uma nação com instituições sólidas e desenvolvidas, e a celebração de nossas virtudes peculiares como povo criativo, flexível e aberto às interações sociais.

É sobre toda essa história do pensamento social brasileiro que Jessé Souza e seus colaboradores, no livro A Ralé Brasileira: quem é e como vive (Editora UFMG, 2009), voltam 

sua crítica que, no mínimo, é capaz de desconcertar tanto os mais bem resolvidos neoconservadores brasileiros quanto aqueles que sempre rogaram para si a luta pela inclusão social, combate à pobreza e superação das lacunas de acesso a direitos em diferentes frentes da cidadania contemporânea (gênero, raça, saúde, sistema penal...). Um verdadeiro petardo nas ideias medianas, bem resolvidas e confortáveis, sobre a brasilidade, o livro demonstra, em uma linguagem límpida e acessível, até mesmo aos menos familiarizados com as narrativas acadêmicas do pensamento social brasileiro, quão frágeis são essas ideias fundadoras do debate sobre a cultura nacional e como desconhecemos aqueles sobre os quais tecemos pressupostos, explicações e abstrações a todo momento: os pobres, ou melhor, para ser fiel à expressão incisiva a que recorrem Jessé Souza e seus colaboradores, a "ralé brasileira".

É também típico de qualquer sociedade, sobretudo as contemporâneas, assoladas por crescente desigualdade interna tanto em termos de renda quanto de acesso ao que Bourdieu denominava de capital simbólico e político, construir ideias e "pré-concepções" sobre os menos favorecidos que nunca coincidem com sua real dinâmica e peculiaridade. Assim, parece ser redundante afirmar que nós, brasileiros, não conhecemos a pobreza, apesar de ela nos assombrar a todo momento, seja no discurso político e econômico, seja na sociabilidade cotidiana. No entanto o livro A Ralé Brasileira vai além desse lugar comum e nos convida a um mergulho mais profundo nessa realidade, abalando até mesmo os pilares que guiam o discurso politicamente correto e engajado em favor dos pobres.

Nos interstícios de uma nação, ao mesmo tempo moderna e arcaica, profissionalizada e desqualificada, institucionalizada e "desinstitucionalizada", cordial e bestializada, a "ralé brasileira" não se constituiria em mero acidente de percurso em direção ao desenvolvimento, como imaginam o pensamento economicista e liberal, nem tampouco estigma de uma nação ainda por construir o acesso a direitos e, portanto, arcaica, como imaginam muitos politicamente engajados no combate à pobreza. Ela seria parte constitutiva da contemporaneidade, muito além da concepção marxista de classes sociais, como próprio substrato de uma sociabilidade contemporânea, marcada pela centralidade do profissionalismo (trabalho), da educação como caminho para o capital simbólico e cultural e da impessoalidade de normas e regras formais e informais de convívio social. Ao contrário de ser um deslocamento dessas tendências, ela é fruto justamente dessas racionalizações às quais se organizam as sociabilidades no mundo atual. Longe de ser substrato mal resolvido de nosso, ainda incompleto, progresso econômico, social e político, ela é justamente parte constitutiva 

desse avanço para o passado e, não necessariamente, uma herança mal resolvida de nossa colonização lusitana, sempre acusada de todos os males da vida social brasileira.

O caminho encontrado por Jessé Souza e seus colaboradores no livro para não escorregar naquilo que, depois da leitura da obra, aparece como pensamento incompleto e até mesmo superficial, tanto num polo da explicação da brasilidade (pensamento liberal econômico) quanto do outro (estudos culturais e politicamente engajados em relação à pobreza), passa pelo reconhecimento da dimensão do indivíduo e das famílias (típico do individualismo metodológico na Sociologia), bem como pela capacidade de reconhecer fenômenos estruturais da sociabilidade brasileira, caminhando por uma seara epistemológica que dialoga com a noção de campos em Bourdieu e até mesmo com a concepção de estruturação de Giddens. Resgatando autores muitas vezes citados, mas pouco lidos e problematizados no mainstream do debate social brasileiro (Simmel, Honneth, ...), o livro cumpre, no mínimo, a função de deslocar as certezas tanto no campo da academia quanto da práxis, sobretudo dos ativistas em políticas, programas e projetos sociais.

Ainda que a obra apresente problemas, que vão desde a repetição de ideias em demasia, passando por certo desequilíbrio na construção dos debates em cada capítulo e algumas interpretações questionáveis dos discursos dos investigados, até chegar a uma lacuna mais propositiva e operativa de ação junto à complexidade dessa "ralé à brasileira", ela merece ser lida e debatida, inclusive pelos menos afeitos às idiossincrasias das reflexões acadêmicas, sob pena de refundarmos a todo instante nossa bem intencionada, mas fadada ao insucesso recorrente, tentativa de construção de um país menos desigual e mais justo.

Ao encararmos de frente a proposição da Plebe Rude (banda de rock dos anos 80), "nunca fomos tão brasileiros", pelas lentes da "Ralé Brasileira", talvez possamos ter mais consciência de nossas incertas certezas, confortáveis diagnósticos e conservadora práxis social, indo ao encontro de nós mesmos como brasileiros. Talvez, assim, possamos dar um passo mais decisivo e promissor em direção ao encontro e diálogo com a "ralé brasileira", o projeto de vida de muitos que se interessam e atuam no campo dos estudos sobre a brasilidade, como eu e, provavelmente, você, caro leitor. 